\title{
Twenty years of economic reform and structural change in the Chinese economy
}

\section{Ross Garnaut*}

On 22 December 1978, the Eleventh Central Committee of the Chinese Communist Party completed its third plenary meeting. There was no contemporary recognition in the West of the significance of the meeting.

The twentieth anniversary of the third plenum received far more attention. In the intervening years, China, and its relations with the international community, have been transformed. China's economy has expanded by five times, and its foreign trade by twelve. It has greatly increased consumption levels of what had been about half of the world's people in poverty. Then an isolated, autarchic economy, China through the mid and late 1990s absorbed about half of the direct foreign investment flows to developing economies. From having no trade or investment ties with Taiwan and the Republic of Korea, it is now the first or second export destination of one and the third of the other.

Even greater has been the transformation of the Chinese mind. Tens of millions of Chinese are now part of an international community of ideas and information. Personal security is provided significantly by the value of people's labour and produce in the market place, in the stead of an intrusive and overwhelming state. With the expanded role of the market has come a substantial widening in the sphere of personal freedom-to travel and communicate with others.

Changes of this dimension and at this extraordinary speed are unsettling, and potentially destabilising. Yet for all the disruption of 
change, and the many new problems that it has generated, most Chinese welcome the transformation. Certainly the large increase in living standards and the expanded sphere of personal freedom are appreciated enough to provide a base for continuity in political leadership and institutions despite the immense stress and dislocation.

Reform in China has not and could never have been a smooth or a painless process. There have been challenges at every step, some bumps in the road, detours, and dead ends. Reform faced its greatest danger in the traumatic aftermath of the Beijing massacre in May 1989 which compounded the risks of an inflationary boom and a major effort to bring it under control. The financial and economic crisis in neighbouring East Asian economies since 1997 is the great challenge of the late 1990s.

\section{The distance travelled: ideas and policy}

Twenty years ago, Deng Xiaoping and his supporters took decisive control of the Central Committee of the Chinese Communist Party. This ended what Deng himself once described in my presence as two years of indecisive economic strategy and policy after the death of Mao Zedong. During those two years, policies embodying pragmatic acceptance of a large role for domestic and international market exchange were in continual contest with the Maoist commitments to local and national autarchy, central planning, state-owned enterprises in the cities and people's communes in the countryside.

Deng and his key supporters were victims of the Cultural Revolution, and the anarchy of that decade was their political launching pad. They were not in any sense political or economic liberals. Deng and his senior supporters had been the managers of the early periods of Communist Party success, in the 1950s before the Great Leap Forward, and in the brief interlude between the recognition of failure in that first lethal experiment in unworldly application of Maoist theory, and the anarchy of the second. They harked back to earlier success, when markets had been allowed to play substantial roles at least in the countryside, within a system in which central planning was supported by a firm administrative order.

The reformist leaders of December 1978 were aware that the world had changed from the earlier, naive days of partial success. They were aware of China's military vulnerability, as an economically weak and technologically backward society. They were deeply conscious that 
China shared the world's longest border with an apparently economically successful, technologically advanced and politically expansionist authoritarian state, the world's second military superpower. Some of them were aware as well that their rivals from the Chinese Civil War across the Taiwan Strait, their compatriots in colonial Hong Kong, and their cold war enemies in southern Korea were enjoying sustained economic success that raised deeply challenging questions about China's own continuing backwardness.

It was the strategic vulnerability that had caused and allowed Premier Zhou Enlai to champion the modernisation of industry, agriculture, science and technology and national defence in the early 1970s, after the armed clashes on the Heilongjiang. The intensification of the SinoSoviet conflict, and the four modernisations, provided the context for diplomatic rapprochement with the United States, and for Deng Xiaoping's temporary rehabilitation as Vice Premier in the early 1970 s. China's national policy lurched dangerously as competing ideas and political forces struggled over the tiller of state. The ultimate directions were settled by the People's Liberation Army's arrest of the 'Gang of Four' after the death of Mao, although policy continued to wobble until Deng Xiaoping's ascendancy in 1978.

Important steps were taken to lay a base for future growth in the period of indecisive policy. The awesome denial of formal education during the Cultural Revolution ended, with the return of competitive entry into the great universities in 1978. China's state enterprises experimented with the purchase of exotic new technologies from abroad. But there were cross-currents and counter-currents, continued ideological contests over high policy, and uncertainty as subordinate leaders watched for the emergence of a clear national direction.

Since December 1978 there has been no turning back.

It is not that Deng and his colleagues obtained endorsement for an elaborate, comprehensive new economic policy or plan. There was no blueprint for China's economic reform and internationalisation-even less than there had been in Taiwan and Korea at the beginnings of their sustained, rapid growth one and a half decades earlier.

But after the 1978 Plenum there was acceptance that domestic and international exchange through markets was a necessary and acceptable component of a national development strategy. There was pragmatic acceptance that institutions and policies that raised national economic output had a valid place in China-summed up in Deng's 
rehabilitation of an early Maoist exhortation to 'seek truth from facts'. These strands were drawn together in the 1987 Party Congress' acceptance of General Secretary Zhao Ziyang's definition of China as a backward country in the 'primary stage of socialism', in which the first national objective had to be the strengthening of the national economy.

The new political environment after 1978 saw foreign trade, direct foreign investment, and the utilisation of external technological cooperation and capital in all forms become acceptable components of national policy. Local experiments with new forms of organisation of agricultural production were legitimised, leading within a few years to the virtually complete replacement of the people's communes with the immensely more productive household responsibility system. Markets became important for exchange for the rapidly expanding agricultural output.

The absence of a comprehensive reform strategy, the eclecticism of economic policy and the gradualism of change have been criticised by foreign observers from time to time over the past two decades. But the absence of a blueprint was an inevitability of China's circumstances, and in practice a virtue.

It was an inevitability because there was no conceptual basis for a market-oriented economy. A few leaders, and a few intellectuals around the edges of policy, had absorbed some of the elements of internationally-oriented growth in Japan, Korea, Taiwan and Hong Kong. But the main understanding grew out of the new patterns of economic development themselves, through observations of the operation of markets within China, and increasing contact with foreign experience and ideas.

Nor was there an ideological basis in the early years for articulation of a model of development based on the operation of markets, deeply integrated into an international economy. Deng Xiaoping's political control of the Chinese Communist party and the People's Liberation Army was strong but not unconditional. It was built partly on others' confidence that he stood firmly for continued Communist Party political dominance, and commitment to some undefined minimum core of socialist principles and objectives.

The absence of a blueprint was a virtue because any theoretical model of reform of the centrally planned economy in China would have been deeply flawed. The rapid unwinding of a centrally planned economy, dominated by state enterprises in the cities and communes in the 
countryside, is fraught with risk of massive dislocation-a reality which was imperfectly understood before the unhappy later experience of Eastern Europe and the former Soviet Union. Some of the great strengths of the Chinese economy in the era of reform came as surprises to Chinese and foreign observers alike and would have been given an inadequate place in a program of reform built upon the received theory and experience of others. First amongst the surprises was the extraordinary dynamism of industrial production in the township and village enterprises that grew from the remnants of the disintegrating people's communes.

Deng Xiaoping used to describe economic reform in China as crossing the river by feeling for stones at each step. Hu Yaobang described reform to Australian Prime Minister Bob Hawke as an experiment without precedent. In the uncertain months following the dismissal of Hu Yaobang from his office of General Secretary of the Chinese Communist Party, Deng alluded uncharacteristically to the Chinese classics in a conversation with the Secretary General of Japan's Liberal Democratic Party, Noboru Takeshita, and compared the path of reform to the mission of Guan Yu, who had had to cross five passes and cut down six generals to achieve his noble objective. ${ }^{1}$

These metaphors contain important insights. Chinese reform required transformations in ideology, in ideas about economic development and policy, in law and regulatory systems and in economic institutions. Above all, it required the accumulation of new knowledge and wisdom in a billion Chinese minds, as the Chinese people learned to do new things in an economic and social world that was fundamentally changed.

These transformations in ideology, ideas, policy, law, institutions, knowledge and experience occurred alongside each other, reinforcing each other. Each created problems for others when it ran into trouble itself.

It took great courage, and faith in some abstract and thinly formed ideas, for the Chinese collective leadership to wade into the river of reform. Courage and faith, and a clear view of the reality-that the maintenance of the status quo in centrally planned China in the aftermath of the Cultural Revolution meant continued backwardness, vulnerability and eventually instability in a rapidly developing East Asia and changing world.

Upon establishing his pre-eminence in the exercise of political power, Deng Xiaoping identified as his agents in the reform of the Party, and of the State and economy, Hu Yaobang and Zhao Ziyang. As General Secretary of the Communist Party, Hu led the task of replacing the 
huge cadre of beneficiaries of the Cultural Revolution with others able to lead and support reform. Zhao was the leader of the practical business of policy reform. Each made extraordinary contributions of leadership and intellect, managing change on a scale and at a pace that was rare in human experience. Each was informed by experience to the view that successful economic reform and development would require a widening of the scope for open discussion of policy, for dissent within the limits set by the imperatives of continued Communist Party rule, and for reform of the political system to make policy somewhat more open to pressures from the rapidly changing society beyond the central leadership. Deng eventually came to doubt the will or the capacity of each to secure and enforce the authority of the Chinese Communist Party, causing the dismissal of $\mathrm{Hu}$ in early 1987 after the Shanghai student demonstrations, and of Zhao, then Party General Secretary, in the Party crisis over the management of the Beijing student demonstrations in May 1989.

The succession after the reform leadership crisis of 1987-89, selected by Deng Xiaoping and until his last years sustained by him, placed a higher premium on stability, and on defining and narrowing the boundaries of discussion of political system change. As it turned out, economic reform and change had its own momentum, that carried along continued social and political change in the local sphere. Li Peng's decade-long Premiership, and the Jiang Zemin leadership of the Party, now approaching the completion of its tenth year, are remarkable for the stability and continuity that they reflect. This stability, in turn, reflected the wider leadership's consciousness of the risk of instability, especially in the period bridging the death of Deng Xiaoping. The emergence of a more activist, reformist Premier in 1998, Zhu Rongji, indicates a return to a sense of urgency in reform and structural change.

In the early years of reform, courage and faith, and a clear view of the futility of standing still, were required in leadership of all state institutions. In the great universities, ageing professors, often with pre-revolutionary experience of academic institutions in the West, were called from the disgrace of the Cultural Revolution to the massive and depressing replacement of half a generation lost to disciplined education. Some leaders of pre-revolutionary business who had opted to make their lives in the mainland, and who had mostly been rewarded by humiliation in the years before reform, accepted invitations to lead market-oriented new state businesses, as examples for the huge and cumbersome 
enterprises that had grown within the framework of central planning. Loyal servants of the state were called to new tasks for which their education and experience had provided no preparation at all.

In one of the boldest of early reform decisions, many tens of thousands of young people were sent or allowed abroad as students-to America, Australia, Japan, Europe and Hong Kong. They became windows of information and of change when they returned to live and work, or more commonly when they returned to visit or simply kept in touch with home.

The conceptual gap that had to be bridged in the course of reform was immense, extending into every corner of economic policy.

To take one corner, the idea that a country can maximise the value of its production and incomes through open trade, relying on imports for goods and services in which the economy has comparative disadvantage, is not intuitively obvious to Chinese any more than to other components of the human species. Even where the logic of comparative advantage is accepted by policymakers, its full reflection in policy is resisted by vested interests that expect to be damaged by it. In China, the usual resistances to specialisation according to comparative advantage were reinforced by the heavy emphasis on autarchy in Communist central planning, by the special Maoist exhortation to 'self reliance', and by the overlay of security concerns about dependence on foreign trade. Inside and outside China there were doubts about the capacity and willingness of the rest of the world to adjust to much higher levels of Chinese exports.

The acceptance of the idea that there are gains in specialisation according to comparative advantage came slowly. Each major sector of the economy became a battleground over acceptance of the concept. The idea gained enough ground for policy change to allow the beginnings of rapid expansion of labour-intensive manufactures balanced by rapid growth in imports of a range of capital-intensive and technologically sophisticated manufactured goods, and of industrial raw materials. The gains from trade then made their own eloquent case for going further. An important milestone was General Secretary Zhao Ziyang's articulation of a coastal economic strategy in early 1988, under which coastal China would expand its export-oriented manufactured export base, building on its relative abundance of labour, and drawing raw materials from international markets.

Resistance to liberalisation remains strong in some sectors, nowhere more so than in grain. But even in grain, the objective has recently 
been stated by the Ministry of Agriculture as 95 per cent, rather than complete, self-sufficiency. The difference would represent about 10 per cent of world trade in grain.

Reform was constrained by the legacy of Chinese Communist Party ideology-specifically, the elements of ideology associated variously with Marx, Lenin, Stalin, and Mao. The ideological legacy of Mao turned out to be the least constraining for economic reform, once the Party had delivered its verdict that Mao was 70 per cent right and 30 per cent wrong. The 70 per cent was the contribution of the early Mao to building the supremacy of the Communist Party, a strong Chinese state, and the early policy which had been developed with the co-operation of Deng Xiaoping and the other, older leaders of the reform period. The excesses of the Great Leap Forward and the Cultural Revolution comprised much of the 30 per cent, including the elevation of ideological purity above the requirements of economic development. On the legacy of Marx, the theoretical distance of classical Marxism from the practical decisions of state, and its denial of the possibility of socialism in a backward country, weakened the constraint that it placed on reform. Some intellectual gymnastics were required in the mid 1980s to render the operation of a labour market consistent with the labour theory of value. What then remained was a commitment to avoid the extremes of income inequality that the Chinese leadership associated with capitalist developing countries, and a view that the state should continue to own the largest enterprises in key economic sectors. The Leninist legacy of firm Communist Party that control through 'democratic centralism' remained a cardinal principle of Deng Xiaoping, has not been successfully challenged and remains a premise of the current leadership. The Stalinist legacy of central planning has had little continuing ideological resonance, at least in the 1990s.

Beyond ideology and policy, there have been immense problems of a highly practical kind, especially in reforming the system of central planning. The practical challenge was how to build the regulatory system, the institutions and the human knowledge and skills to implement reform policy and to make the partially reformed system work. Amongst the most difficult tasks has been the building of an institutional framework to implement monetary and therefore macroeconomic stabilisation indirectly, as is necessary in a market economy. Through the first one 
and a half decades of reform, weaknesses in this area had generated a cycle in growth, inflationary and balance of payments pressure that seemed to be widening over time (Garnaut and Ma 1993a). The apparent 'soft landing' after the inflationary boom of 1993-95 is suggestive of progress, although the role that continued to be played by costly direct controls on investment during this episode qualifies the success. By the mid 1990s it was clear to the government that sustained stable growth required the completion of the reform of stateowned enterprises, allowing, finally, enforcement of hard budget constraints. The 1997 Party Congress and 1998 National People's Congress laid a base for rapid progress, which has as yet been only partially utilised.

At the end of the 1990s, the practical problems centred on the threat of contagion from the East Asian crisis. This was--and indeed still is-a massive challenge, threatening stability and growth.

The larger perspective is that the reform and internationalisation of the Chinese economy is an undertaking of such immense dimensions, and unusual character, that it is inevitably challenged in ways that are potentially dangerous to its successful conclusion. The contemporary challenge is dangerous, but not especially large compared with the passes that have already been crossed, and in particular the barriers of ideology, ideas, policy, institutions and practical difficulties that faced the reformers at the beginning.

\section{The distance travelled: economic change}

China's real economy expanded strongly with reform. Over these two decades, China has emerged as the most dynamic large player in the world economy. Growth in output and in external economic relations has been as rapid in China as in any of the East Asian economies in their own periods of strong growth, although China happens to have been excluded from the World Bank's ill-fated East Asian Miracle (World Bank 1993a).

Figures 1.1 to 1.7 summarise the story of growth and structural change in output and foreign economic relations in a series of charts, taken from the standard data accepted and published by the international agencies.

Can we believe the statistics? This question was asked with more urgency as China claimed success in maintaining growth near 8 per cent through the East Asian crisis in 1998. 
The external trade and investment data are broadly confirmed from other countries' records of the same transactions. The main questions focus on the domestic output data.

There are some conceptual problems with the conventions of the standard national accounts. They measure increases in stocks as valuable production, even when the discounted present value of future sales is low. This is not only a problem in China-it arises in advanced market economies in recession. But it is a larger problem when stocks held by government-supported state enterprises are rising rapidly. There are problems of valuing non-marketed services in all economies, and a larger problem in economies like China where this sector is large, leading

Figure 1.1 Proportionate increase in real output, 1978-98 (per cent)

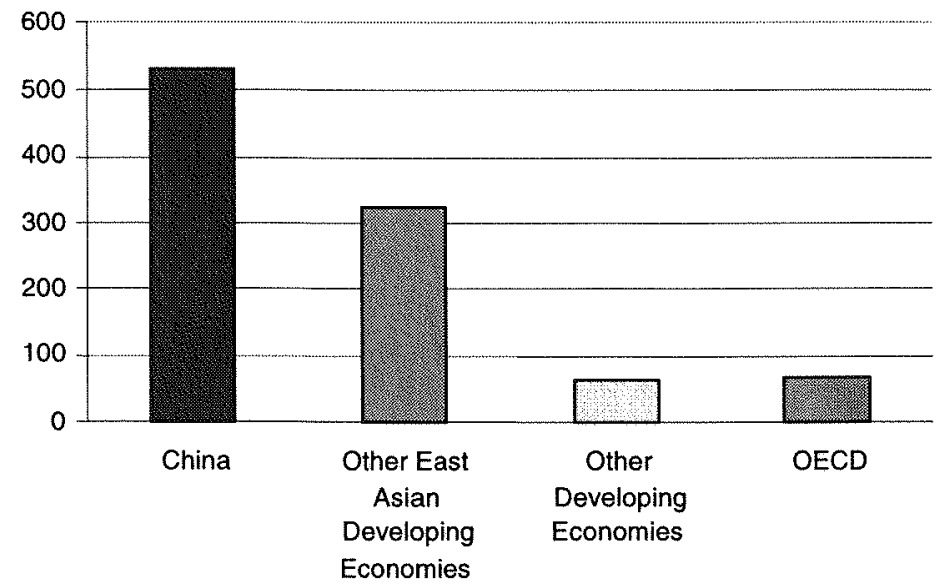

Sources: Author's calculations based on data compiled from World Bank, 1997. World Development Indicators, World Bank Publications, Philadelphia [CD-ROM]; International Monetary Fund, (various years). World Economic Outlook (various issues), International Monetary Fund, Washington, DC; International Economic Databank, The Australian National University, Canberra. 
Figure 1.2 Structural changes in China, 1978-97 (industrial output by ownership, per cent of total, total $=100$ )

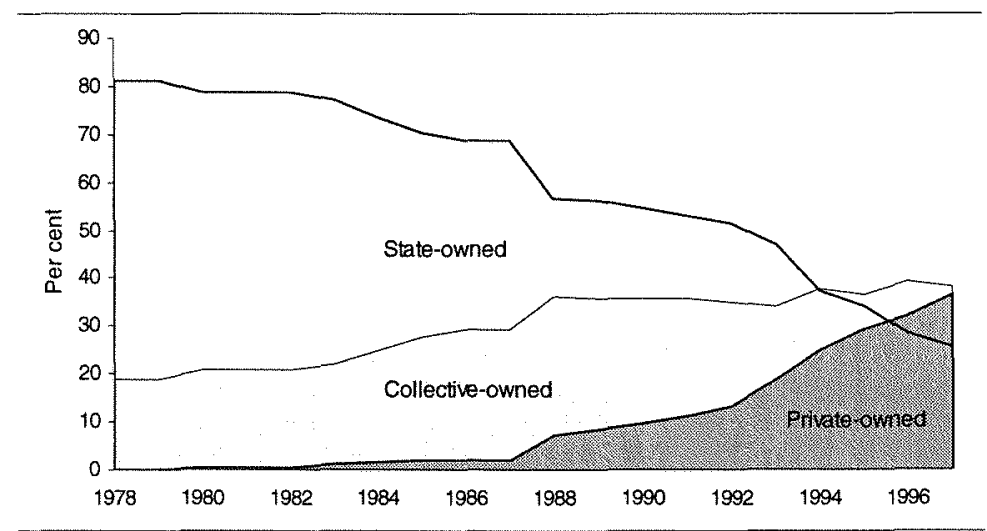

Source: State Statistical Bureau, (various years). Statistical Yearbook of China, China Statistical Publishing House, Beijing.

Figure 1.3 Employment in township and village enterprises, 1978-97

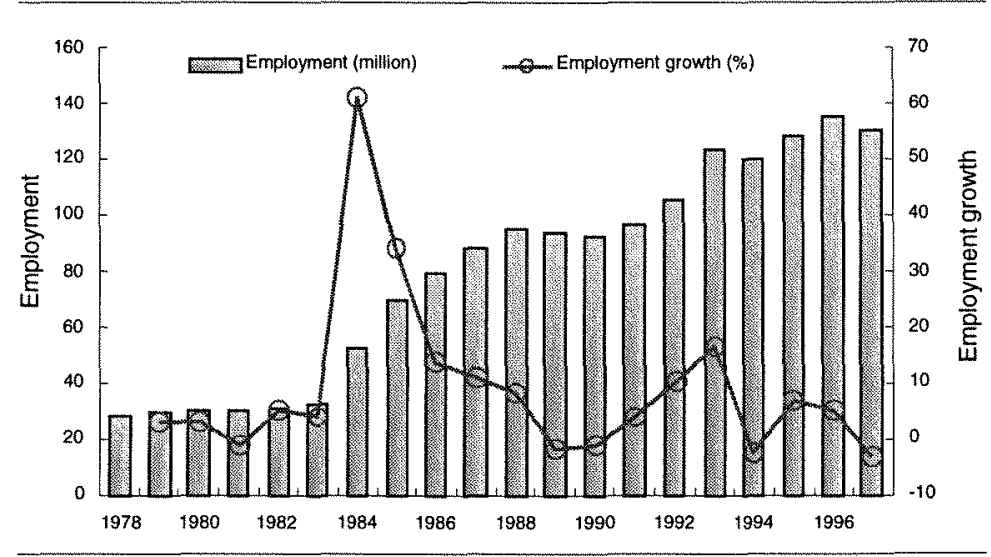

Source: State Statistical Bureau, (various years). Statistical Yearbook of China, China Statistical Publishing House, Beijing. 


\section{Figure 1.4 Exports of large developing countries and Australia, 1978-98 (US\$billion)}

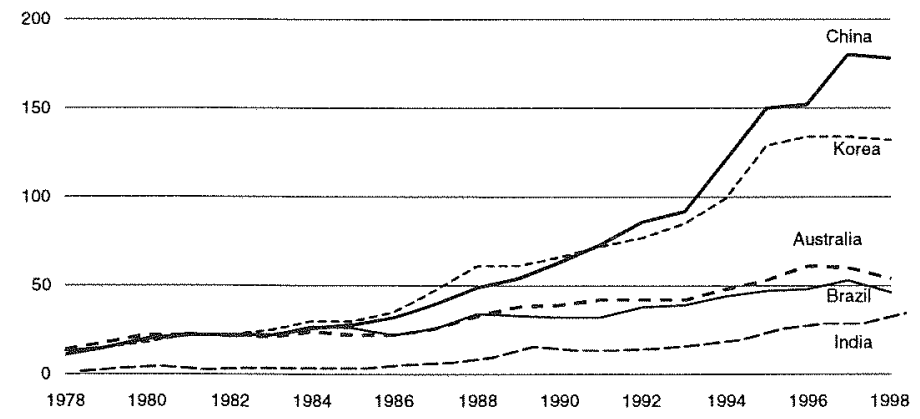

Source: Author's calculations based on data compiled from United Nations COMTRADE database, International Economic Databank, The Australian National University, Canberra.

Figure 1.5 Proportionate growth of exports (constant prices), 1978-98 (per cent)

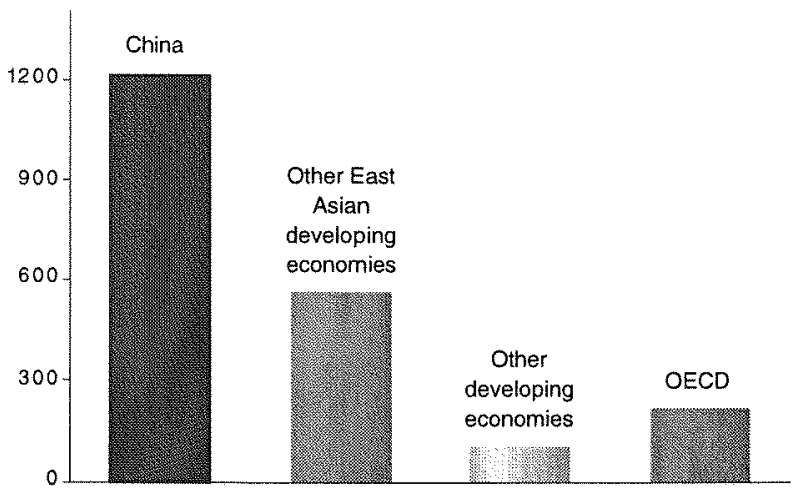

Source: Author's calculations based on data compiled from United Nations COMTRADE database, International Economic Databank, The Australian National University, Canberra. 
Figure 1.6 China: changes in composition of exports, 1978-96 (per cent)

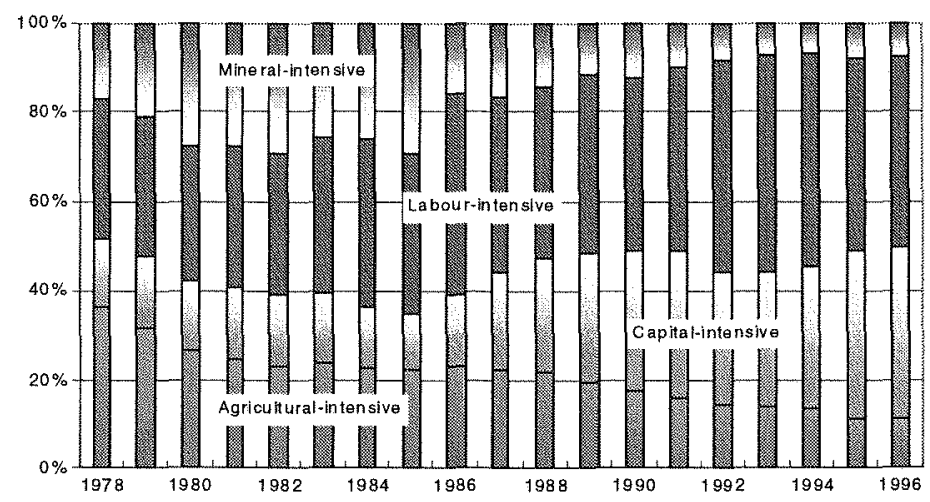

Source: Author's calculations based on data compiled from United Nations COMTRADE database, International Economic Databank, The Australian National University, Canberra.

Figure 1.7 Developing economy shares of world exports in labour-intensive manufactures, 1978-96 (per cent)

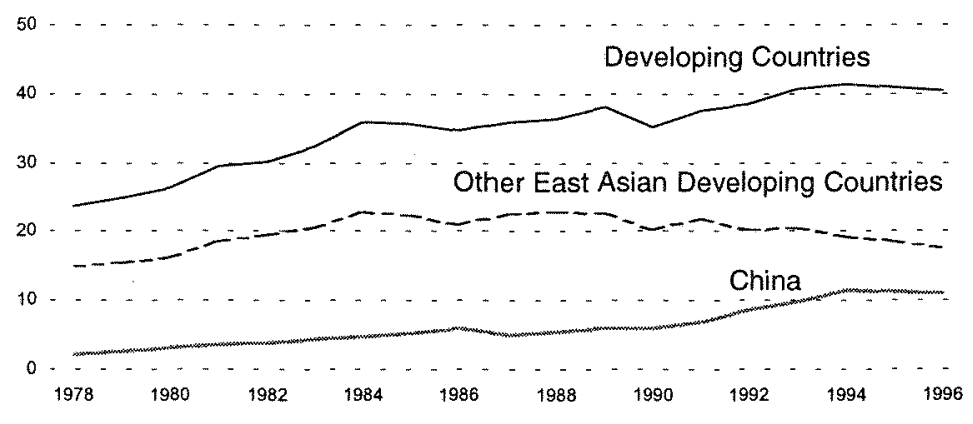

Source: Author's calculations based on data compiled from United Nations COMTRADE database, International Economic Databank, The Australian National University, Canberra. 
to underestimation of the level, although not necessarily the growth, in output. In all economies there are problems in bringing natural resource depletion and environmental degradation or enhancement to account in assessment of the growth of valuable economic output, and this is especially important in low income developing economies experiencing rapid industrialisation.

The professional quality of China's statistical collections has improved greatly since the early years of reform. Nevertheless, there are continuing problems in China beyond those that are present in all national accounts. One is a difficulty in valuing output in the township and village enterprises. The weight of informed professional opinion suggests that this may lead to over-estimation of real growth on average by up to 2.5 per cent per annum over the reform period. For example, Maddison (1998) measures the over-estimation at 2.4 per cent or 0.1 per cent, depending on the sectoral weights that are applied. The Maddison logic suggests that the over-estimation would be less important at times of low-inflation, such as the present.

There is a difficulty in reconciling reported data on levels of output over time with reported growth rates, and observed levels of consumption, use and trade in a wide variety of commodities in China and in other developing economies. Garnaut and $\mathrm{Ma}$ (1993b) examined this issue and concluded that the standard national accounts, converted into foreign currencies at official exchange rates, undervalued Chinese output relative to other developing economies with low and middle incomes by a factor of three. The large real appreciation of the renminbi since early 1994 and especially through the East Asian crisis would have reduced the relative overvaluation substantially.

The overall story is that, leaving aside the general conceptual problems of the national accounts in all countries, the Chinese data substantially understate the size and average incomes of the Chinese economy, moderately overstate output growth rates, and give a reasonable picture of the scale and growth of China's interaction with the international economy.

There is a separate issue concerning the relationship between GDP as measured in the national accounts, and the purchasing power of GDP. The standard national accounts data underestimate the purchasing power of lower relative to higher income countries. This simply reflects the lower valuation in the national accounts of labour and non-tradable goods and services in a low-income economy. 
This is the reason why China looms much larger in the 'purchasing power parity' estimates of economic size, than it does in the national accounts data. The difference in relative "incomes and size resulting from this influence alone is typically a factor of two or three in low income countries. This relative undervaluation of the volume of goods and services produced in low income countries disappears as labour becomes more valuable in the course of economic development. The phasing out of the relative undervaluation explains a general tendency for rapidly growing developing economies to catch up with the world economic frontiers more rapidly than the initial income differences and the growth rate differentials would suggest.

\section{China and the East Asian crisis}

China's growth and structural change in the reform era has had much in common with other East Asian economies at corresponding periods of their own development. This was once a comfort, when there was none amongst the East Asian economies that had grown fast enough to double output in a single decade, that had failed to sustain strong growth until it had been lifted to the frontiers of world productivity and average incomes. Growth slowed in Japan from the mid 1970s, and in Hong Kong and Taiwan in the 1990s, but only after these economies' average incomes had entered the range of advanced industrial economies.

Now the question is being asked, whether the crisis in the economies of many of China's neighbours suggests that China can be expected to enter a period of economic instability and slower growth.

Certainly the East Asian crisis is the greatest external challenge of the past twenty years to stability and growth in China. So far China has had a relatively good crisis, sustaining growth at high levels (although down on the twenty-year average) in the second half of 1998 through massive fiscal expansion, and winning much international kudos for this and for holding the pre-crisis US dollar value of the renminbi.

At the time of the twentieth anniversary of reform, and still in early 1999, a view was emanating from the foreign community in Beijing and the business community in Hong Kong that China had not really done so well through the crisis, or that it would run into deep trouble in the near future. This view had its origin in incredulity that China, with structural flaws in its financial system as large as any in the region, could avoid the problems that had defeated apparently stronger economies. 
The East Asian crisis has certainly been a large blow for mainland China. The East Asian economies that are currently in recession, including China's Northeast Asian neighbours, Korea, Hong Kong and Japan, account for half China's exports and three-quarters of its direct foreign investment. The East Asian orientation of China's trade and investment was an advantage when the rest of the region was growing strongly. In 1998 it was a large drag on performance, with East Asian imports from the world as a whole declining by 17.3 per cent in 1998 (Figure 1.8).

In these circumstances, even if China held its share in total imports of other East Asian economies-not an easy task given the heightened competitiveness of others-it would have to expand exports beyond East Asia well above 30 per cent per annum if total exports were to continue to grow at a rate near the average of the reform period. This is simply impractical, if only because of the protectionist response it would generate. In fact, China's export growth slumped through 1998, going strongly and at first sight dangerously into negative territory from October (Figure 1.9). At the same time, the weak real exchange rates of other East Asian economies through the crisis reduced pressure and capacity for direct foreign investment, including to China.

China stood up well to the East Asian crisis, at least through its first year and a half, because its macroeconomic fundamentals were strong at the onset of crisis. Inflation was low in response to the corrective policies applied mid-decade. The current account of the balance of payments, and export momentum were strong. A recent history of high levels of direct foreign investment and reform was generating considerable productivity growth in the export industries. High levels of capital inflow were mainly in the form of direct foreign investment, with controls on capital movement inhibiting inflows of speculative portfolio capital. Foreign exchange reserves were high-second only to Japan in global terms - and rising.

These strengths at the onset of the crisis allowed China to implement a massive fiscal expansion to offset the recessionary impulses from the external sector. This was cutting in powerfully from the third quarter of 1998.

China chose early in the crisis to maintain the US dollar value of the renminbi, at least through 1998, and perhaps indefinitely. In late 1998, leaders of the government and of the People's Bank of China stated firmly that China intended to maintain the rate at least through 1999. 
The motive of the exchange rate policy was primarily domestic: to avoid the inflation and pressure on financial and other businesses that had accompanied massive depreciation elsewhere in East Asia. The maintenance of growth and the old exchange rate parity reduced the pressure on the weak financial system. China's policy of maintaining the exchange rate and supporting growth with fiscal expansion was favourable to eventual stabilisation and recovery elsewhere in the region. China's imports from other East Asian economies held up reasonably well through 1998 (Figure 1.10). Favourable international feedback encouraged China to persist with the policy.

\section{Figure 1.8 Growth in East Asian imports, 1985-98} (per cent per annum)

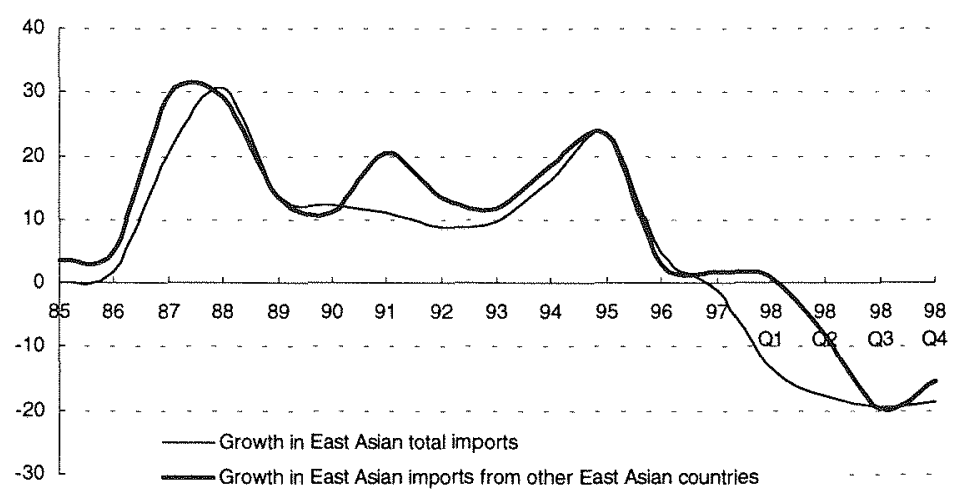

Note: Quarterly data represent change on corresponding period of previous year.

Source: Author's calculations based on data collected from International Monetary Fund, (various years). Direction of Trade, International Monetary Fund and International Bank for Reconstruction and Development, Washington; China, (various years). China Monthly Statistics, China. Statistical Information and Consultancy Service Centre, Peiching; various country sources. 
Can this approach be maintained? Or does the sharp downturn in exports from October 1998 portend an eventual depreciation, abandonment of fiscal expansion, and recession, with the contraction of the economy being intensified greatly by these factors' interactions with a chronically weak financial system?

China could not sustain for many years fiscal deficits on the scale of 1998 and that proposed for 1999 . Nor could it sustain indefinitely an appreciation of its real effective exchange rate on the scale of early 1998 , against its East Asian trading partners and competitors. This was the reason for its pressure on Japan when the yen was at its weakest point in mid 1998. Eventually the unmanageably large decline in competitiveness can be corrected by declining costs and prices in China, inflation in other countries, faster productivity growth in China than in trading partners and competitors, and by recovery in the economies and re-appreciation in the exchange rates of other East Asian countries.

\section{Figure 1.9 Growth in China's exports, 1985-98 (per cent)}

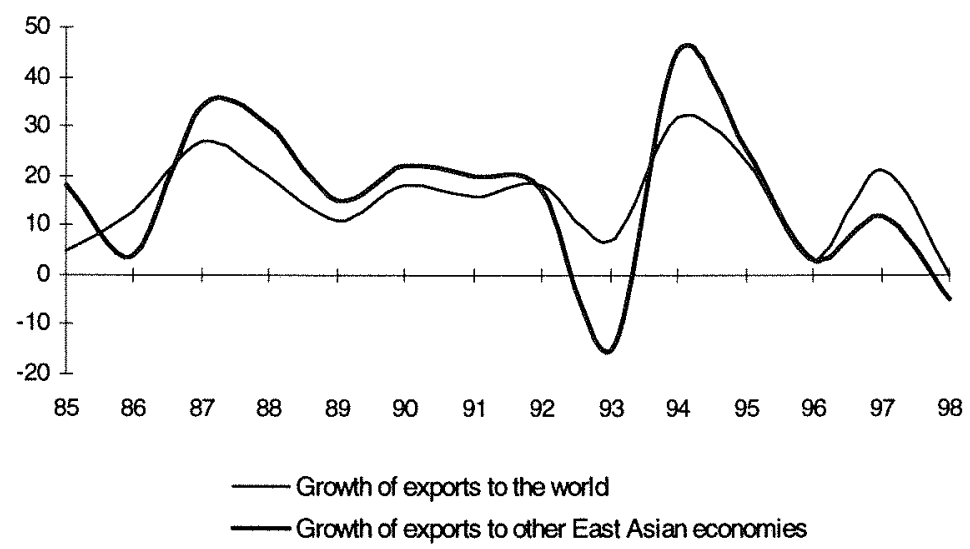

Sources: Author's calculations based on data collected from State Statistical Bureau, (various years). Statistical Yearbook of China, China Statistical Publishing House, Beijing; China, (various years). China Monthly Statistics, China Statistical Information and Consultancy Service Centre, Peiching; International Monetary Fund, (various years). International Financial Statistics, International Monetary Fund, Washington; various country sources. 
There are recent signs of favourable movement in several of these parameters. Figure 1.11 sets out the data for China's average real exchange rate.

Financial markets in the East Asian economies in recession have been stronger since late September 1998. This in itself takes pressure from the Chinese exchange rate and economy, and indicates expectations of recovery in at least some economies. So long as these expectations come to be realised in 1999, China will be able to hold on to its late 1998 strategy.

That is not to say that the weakness of China's financial institutions can be seen as anything other than major potential threats to growth, requiring firm correction. This problem is less urgent in China because the state stands unequivocally behind the banks that it owns, turning a potential financial crisis into a potential budget problem. The Chinese fiscal system seems able to handle the load in the immediate

Figure 1.10 Growth in China's imports, 1985-98 (per cent per annum)

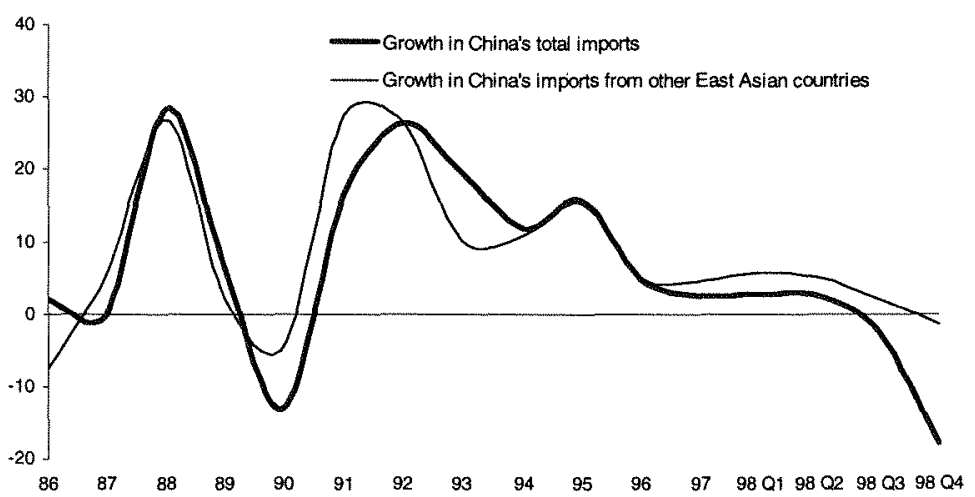

Note: Quarterly data represent change on corresponding period of previous year.

Sources: Author's calculations based on data collected from International Monetary Fund, (various years). Direction of Trade, International Monetary Fund and International Bank for Reconstruction and Development, Washington; China, (various years). China Monthly Statistics, China Statistical information and Consultancy Service Centre, Peiching. 
future, but not indefinitely without correction of the underlying weaknesses.

The Chinese authorities have learned the main lesson of the East Asian crisis-that the strengthening of the regulatory and institutional framework of the banking system is of high national importance and that in China this requires early completion of the reform of state-owned enterprises. They have learned another lesson as well-that free capital flows carry risks, and that capital convertibility should be placed on hold. The reflection of this apparent lesson in policy in itself may not impose large costs, but it will do so if capital controls reduce the urgency that is applied to financial sector reforms.

While the exchange rate and fiscal policy responses to the crisis have so far been well judged, the exchange rate may not and the fiscal expansion will not be sustainable much beyond 1999. So 1999 is a year in which the authorities have some space to undertake much of the analytic work and some of the policy action in the financial sector that is necessary to support growth into the long-term future.

Already some of the policy actions taken in support of the fixed exchange rate are damaging to growth, including the restoration of much of the earlier large role of state enterprises in grain marketing and price management, and the tolerance of price-fixing cartels to resist falls in prices in a number of sectors in which state-owned enterprises play important producer roles.

One of the objectives of contemporary work on financial reform should be to build the institutions that are necessary smoothly to replace the pegged exchange rate with a floating rate regime. In the first six months of the East Asian crisis there was upward pressure on the foreign exchange value of the renminbi, with foreign exchange reserves rising. The pressure is now strongly downward, with large speculative outflows of capital despite the capital controls. The current downward pressure may intensify, becoming a large problem for domestic economic performance. To move the peg downwards by a discrete amount in 


\section{Figure 1.11 China in the East Asian crisis, competitiveness} index, $1990=100$

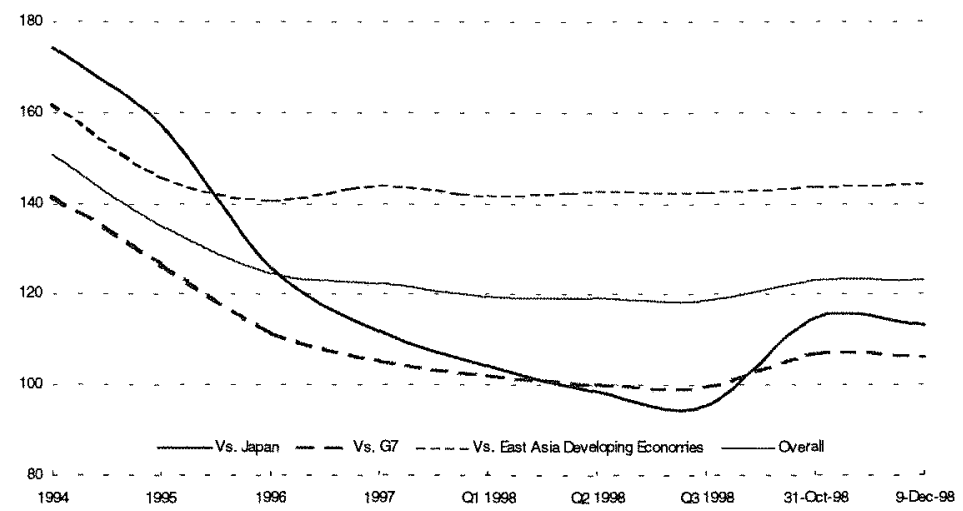

Note: The competitiveness index is a trade share weighted average real exchange rate. It is calculated based on the following formula

$$
R R_{i}^{i}=\sum_{j}^{n} \alpha_{i j i}\left(\frac{e_{t}^{i}}{e_{i}^{j}}\right)_{i n d e r} \cdot\left(\frac{p_{t}^{j}}{P_{t}^{i}}\right)
$$

where $R E R_{t}^{i}$ denotes country is real exchange rate at time $t$, superscripts $j$ denotes trade partner country, $\alpha_{i j t}$ stands for the share of country is exports to country $j$ in country is total exports at time $t . e_{t}$ is country $i$ or $j$ s nominal exchange rate against US $\$$ at time $t . P_{t}$ is country $i$ or is consumer price index at time $t$. The ratio of nominal exchange rate between country $i$ and $j$ is indexed $(1990=100)$ in order to remove the effects of difference in currency units.

Source: Data for trade shares are collected from Direction of Trade, International Monetary Fund (IMF). Data for nominal exchange rate and consumer price index are collected from International Financial Statistics (IMF) and various country sources; Asia Pacific Economics Group, 1998. Asia Pacific Profiles 1998, FT (Asia Pacific), Singapore. 
response to any such development would risk misjudgment and the intensification of uncertainty.

The best course now would be to let it be known that the authorities were working on the institutional reform that was necessary for a floating exchange rate to be successful. The authorities could then credibly state that the next move in the exchange rate against the US dollar would be a float, and not a discrete devaluation. The authorities could provide assurances that the next move would not take place in 1999, and may not take place soon after. The market would be asked to judge upon both the direction and the extent of any change in parity. A mechanism would be on hand to allow flexibility without loss of policy credibility should circumstances over the next few years require it.

\section{Where is growth going and when will it end?}

The experience of East Asia in the past half century, and of China in the two decades of reform, tells us that sustained, rapid economic growth is no 'miracle'. Rather, it is a normal part of the human condition in a poor country, which meets a number of conditions for growth.

Rapid economic growth in the postwar East Asian style is a process of catching up with the world's advanced economies, from a low base. It involves catching up technologically, by drawing on the knowledge and techniques of advanced economies through a range of mechanisms. It involves catching up in the amount of capital available for each worker to use, through high savings and investment and through the use of foreign capital. The accumulation of human capital through education and experience is important to the process. Economic growth involves the allocation of capital and labour to more and more productive uses, through the use of markets at home and open trade that allows international specialisation in line with comparative advantage as it changes over time. All of these conditions require economic policy to deliver a reasonable degree of economic stability.

When the policy conditions allow it, economic growth can proceed more rapidly in a poor country, because a wider technological gap from the world's frontiers allows more rapid technological improvement. Growth can proceed more rapidly in a densely populated poor country 
because the gains from trade are greater in a country whose resource endowments are very different from the advanced economies.

Rapid economic growth is a stressful process. It forces changes in the industries and locations in which people are employed and the way jobs are done. It churns and re-orders economic and political élites. It can destabilise the political order that is responsible for the policies that sustain it unless the political order itself evolves with the economic structure. At the same time, the capacity to support rising living standards that are generated by economic growth is a salve to the stress of structural change if its benefits are distributed widely. The dispersion of the distribution itself is affected by some factors that are beyond the control of governments. Importantly, a wide distribution of the benefits of internationally-oriented economic growth is facilitated in a densely populated country in which employment and labour incomes grow exceptionally as it opens to foreign trade. This helps China, as it helped other East Asian economies before it. But China's size, poor internal transport and communications, and wide variation in the natural and human resource base for development increase the challenge of maintaining an acceptably broad distribution of the benefits of growth. Acceptable dispersion of the gains from growth in China, more so than in other East Asian economies, is therefore significantly reliant on sound policy choice.

Perfect policy is not a necessary condition for rapid economic growth to proceed. Protectionist policies that reduce the gains from trade, market imperfections that keep some resources in relatively unproductive uses, periods of economic instability that inhibit the accumulation of capital, inadequate public investment in education and infrastructure-all of these hold growth back from attainable levels, but, depending on their extent, may not be inconsistent with rapid growth. As growth proceeds, and the frontiers of world technology and living standards are approached, the tolerance of growth to weaknesses in policy and institutions declines. In particular, the costs of poor policies affecting income distribution become larger over time.

Because it is so stressful, rapid economic growth does not proceed unless the view is widely held in society that it is a prime objective. Growth attained this status in 1978 in China, and has retained it since.

Rapid growth is easier to sustain than to initiate. Rising incomes are more effective in allaying doubts and allaying resistance to change when 
they are a current reality rather than a hope and a promise. Savings rates rise with rapid growth, supporting the growth process.

Nevertheless, the old as well as the new experience of East Asia, and the older experience of industrialisation in the West, tell us that growth and modernisation do not proceed in logarithmic straight lines. There is a strong tendency for them to proceed until the world's economic frontiers are reached, but they can be broken temporarily or permanently by adverse developments of several kinds. Booms and manias, followed by economic collapse, are ever-present risks of market economies and sometimes result in major lurches in policy that block a return to growth. Poor policy-resulting from professional weakness or political manifestations of resistance to change-can block the continual reallocation of resources to more productive uses. A failure of the political institutions to adjust to the changing structure and aspirations of the community can undermine social and political cohesion around the objective of growth.

Any one of these risks could emerge to block China's modernisation and continued growth. It is not likely that these risks will crystallise in China into a collapse of growth as in the East Asian crisis, for reasons that I have already set out. But there will be plenty of other risks and challenges, some arising when China is less well placed to handle them than in 1997.

There is another possibility, that is more closely consistent with the experience of the past twenty years. Within this prospect, ideas about policy, policy itself, institutions, and the knowledge of Chinese people, evolve with the experience of rapid growth, in ways which sustain it. The rapid growth which has been concentrated amongst a few hundred million people in the coastal provinces, spreads inland, as regulatory and infrastuctural barriers to internal trade are removed. It is unlikely, and at odds with the experience of others, that there would be no setback to rapid growth-no recessionary end to a market mania, no large misjudgment of macroeconomic policy, no failure of leadership nerve or judgment on continued market reform. But is it possible that for a long period ahead, as in these past twenty years, the realisation of the national and personal benefits of growth, and awareness of the conditions that sustain it, will be sufficiently widespread and strong to return China to a growth path whenever it is temporarily knocked from it?

Within this prospect, which the experience of the reform period suggests is more likely than not, the average growth of the last two decades will be sustained for several decades more. Output will double 
each decade. In another two decades, China will be the world's second largest economy by conventional national accounts measures in output and foreign trade, or third if the European Union by then is seen as a single entity. By the end of these two decades, the dynamic coastal provinces-several hundred million people-will enjoy living standards broadly at the level of Taiwan today.

Economic growth can always end with political convulsion that removes the primacy of the growth objective. This would become a greater risk in China if policy were ineffective in allowing the spread of economic growth into the vast inland. This is an avoidable outcome, with awareness of the issue and good policy.

Economic growth in China will not end in global famine, as has been contended famously. Global markets can handle the growing demand for food that rising incomes in China would generate.

It will not end in national environmental catastrophe. Rising incomes are bringing both the will and the capacity to do something about the environmental degeneration that has been associated with urbanisation and industrialisation in China. China's sustained, rapid growth raises larger, global environmental issues, but not just for China.

In two decades, China will face a huge challenge of demographic transition, when the one child family is entering middle age and the number of young workers is shrinking sharply. This will be much on the minds of leaders if there is a $19^{\text {th }}$ Party Congress in 2017, as a threat to the longer term dynamism of Chinese society and economy.

But two decades hence would be an unlikely place for the growth process that began with reform to end. The modernisation of the vast inland of China will be in its early years. It is more likely that Chinese society, aware as never before of the pain and costs of growth, will choose to push ahead. It will be a natural and in no way a miraculous outcome if the growth of China's past two decades continues until most of China's people enjoy living standards and productivity levels close to those in the world's most advanced economies. 


\section{Notes}

" I am grateful to Xu Xinpeng for assisting me in putting together the statistical material for this chapter, and to Song Ligang for helpful comments on an earlier draft. This paper was delivered to the Australian China Business Council, Melbourne, 25 November 1998. ${ }^{1}$ When Takeshita visited the Australian National University in November 1998 , I reminded him of the 1987 conversation, reported at the time in the Chinese press. He remembered it more for Deng Xiaoping's imprecision in the numbers and details of economic policy than for his classical allusion! 